\title{
THE THEORY AND PRACTICE OF URBAN AND SPATIAL PLANNING IN ROMANIA
}

\author{
A B S T R A C T
}

Different theoreticians place urbanism among sciences, arts, activities, or regulations, also accounting for its final product. The methods of urbanism include strategic planning, urban compositions, participative, managerial, and communication urbanism. All these conceptual and methodological sides are found in the Romanian approach to urbanism, making it representative as a case study. Therefore, the aim of this paper is to analyze the theoretical and practical approaches to urban and spatial planning in Romania from a historical perspective. The conclusions of the analysis indicate that territorial planning in Romania has two levels - urbanism and spatial planning, both resulting into urban/spatial planning documents. The elaboration and approval of these documents is subject to numerous laws changing rapidly, controlled by local and central authorities, and involves a long and complicated bureaucratic process. The accession of Romania to the European Union determined changes of this process, as well as a set of changes in the education system preparing the future professionals. The relevance of the results could be extended to formerly communist countries joining the European Union. 


\section{INTRODUCTION：DEFINING THE URBANISM}

According to the principles of classic logics, a definition must first place its object in an already established class, and then expose the features that differentiate it from the others members of the class. However, when applying these principles to urbanism, the first problem is to identify the larger class. Different definitions consider that urbanism is an activity or its product, a science or an art, or a system of regulations. Currently, the 1965 definition is in place when looking at the final product: civil engineering works, plans of the cities, and urban forms characterizing each age (Choay, 1965). However, the 1995 definition places urbanism among arts and sciences; urbanism is the science and theory of human settlements, a discipline derived from arts, but different from them through its reflexive and critical character, which turns it into a science (Péchoin, 1995). Definitions found in the legislation place urbanism among regulations - assembly of rules governing the birth, development and management of urban agglomerations (Urbanproiect, 2004) or activities - the operational, integrator and normative activity aiming to stimulate the complex evolution of settlements through short, medium, and long term strategies of development (The Parliament of Romania, 2001a).

According to Lacaze (1990), the methods of urbanism include strategic planning, urban compositions, participative, managerial, and communication urbanism. All these sides are found in the Romanian approach to spatial planning, involving a description of the current status of a given territory, identifying its problems and needs, and proposing a development strategy in order to valorize the existing potential and resolve its problems, provided an input from the population. Upon completion, the plan is presented to the local (or central authorities) and technical committees, who are able to ask for indepth analyses before the final approval.

Since the approaches to urbanism cover in Romania all these theoretical and practical sides, provided the existence of a theoretical background interrelated with the aesthetical viewpoint of the planner attempting to respond to practical questions while abiding to specific regulations, this paper aims to analyze urban and spatial planning in Romania as a case study illustrating most theoretical and practical developments of the discipline.

\section{DEFINING THE URBAN AREAS}

Obviously, the next arising question concerns the relationship between urbanism and urban areas. Whereas in Romania the concept of urbanism 
relates to both urban and rural settlements, other laws discuss what is called an urban area. Worldwide, the criteria for defining the urban areas include a minimum density of population: $620 / / \mathrm{km}^{2}$ according to the United States Census Bureau (McIntyre, Knowles-Yánez şi Hope, 2000), a minimum population - 1,500 in Ireland, 2,000 in France, 5,000 in Romania (Petrişor, 2008), or the fact that the largest share of population is employed in nonagricultural sectors. Other definitions include: (1) one (rarely two) central city with a population of at least 50,000 residents and the neighboring area - the urban area is the physical city regardless of political or administrative limits, (2) regions densely populated (Urbanproiect, 2004), (3) other definitions, according to the discipline, presented in Table 1.

\section{HIERARCHY OF SETTLEMENTS. STATISTICAL VERSUS ADMINISTRATIVE UNITS}

According to the Romanian Constitution (article 3, §(3)), the territory is administratively divided in communes (which can include several villages), cities, and counties. By law, some cities acquire a higher status, namely municipality. All these administrative units have their own local governing structure.

The main quantitative and qualitative indicators used to define urban settlements and differentiate between cities and municipalities are defined by the Romanian Law no. 351 of 2001 on the approval of Section IV of the National Spatial Plan (Table 2). However, there are cities and municipalities not meeting the minimum criteria. The same law establishes six ranks of human settlements: 0 - the capital (Bucharest), municipality of European

\begin{tabular}{|l|l|l|}
\hline \hline Author & Discipline & Definition \\
\hline \hline Emlen, 1974 & Ecology & Region formed by houses and adjacent green spaces \\
\hline Erskine, 1992 & Ecology & Built-up area \\
\hline Odum, 1997 & Ecology & Area using $100.000 \mathrm{kcal} / \mathrm{m}^{2} / \mathrm{an}$ (energy) \\
\hline United States Census Bureau & Sociology & Area with a density over $620 / \mathrm{km}^{2}$ \\
\hline United Nations, 1968 & Sociology & Settlement with over 20,000 people \\
\hline $\begin{array}{l}\text { Mills and Hamilton, } \\
1989\end{array}$ & Economy & $\begin{array}{l}\text { Settlement with certain minimum population and minimum } \\
\text { housing density }\end{array}$ \\
\hline $\begin{array}{l}\text { Herzog and Chernick, } \\
2000\end{array}$ & Psychology & $\begin{array}{l}\text { Settlement with a walk path between building, asphalted } \\
\text { parking lots and older buildings in the rear }\end{array}$ \\
\hline $\begin{array}{l}\text { Hendrix, Fabos } \\
\text { and Price, 1988 }\end{array}$ & Planning & $\begin{array}{l}\text { Residential area with over } 1 \text { residential building } / 4,000 \mathrm{~m}^{2}, \\
\text { commercial and public institutions, railroad depots, truck } \\
\text { parking spaces, and roads }\end{array}$ \\
\hline
\end{tabular}




\begin{tabular}{|c|c|c|}
\hline Minimal indicators & Municipality & City \\
\hline Population & 25,000 & 5,000 \\
\hline $\begin{array}{l}\text { Share of population in non- } \\
\text { agricultural sectors }\end{array}$ & 85 & 75 \\
\hline$\%$ houses with water supplies & 80 & 70 \\
\hline $\begin{array}{l}\% \text { of houses with indoor } \\
\text { bathroom/toilet }\end{array}$ & 75 & 55 \\
\hline $\mathrm{N}^{\circ}$ of hospital beds / 1,000 p people & 10 & 7 \\
\hline $\mathrm{N}^{o}$ of physicians / 1,000 people & 2.3 & 1.8 \\
\hline Education & Post-high school & $\begin{array}{l}\text { Post-high school, other } \\
\text { secondary education }\end{array}$ \\
\hline Culture and sports & $\begin{array}{l}\text { Showrooms, eventually theaters, } \\
\text { musical institutions, public } \\
\text { libraries, stadium, sport halls }\end{array}$ & $\begin{array}{l}\text { Showrooms, public libraries, } \\
\text { spaces for sports }\end{array}$ \\
\hline Hotel rooms & 100 & 50 \\
\hline Modernized streets (\% street length) & 60 & 50 \\
\hline Water supply (\% street length) & 70 & 60 \\
\hline Sewerage pipes (\% street length) & 60 & 50 \\
\hline Wastewater treatment & Mechanical and biological treatment & Mechanical treatment \\
\hline Outer hydrant (\% street length) & 70 & 60 \\
\hline $\begin{array}{l}\text { Green spaces (parks, public } \\
\text { gardens, squares) }-\mathrm{m}^{2} / \text { people }\end{array}$ & 15 & 10 \\
\hline $\begin{array}{l}\text { Controlled storage of } \\
\text { waste(secured access) }\end{array}$ & Public park & Public garden \\
\hline
\end{tabular}

Table 2: Defining cities and municipalities in Romania: the main indicators

importance, I - municipalities of national importance, and potential European influence, II - municipalities of inter-county or county importance or playing a role in balancing the network of settlements, III - cities, IV - villages residence of communes, and $\mathrm{V}$ - villages composing communes or belonging to the municipalities of cities.

The Romanian territory is divided in eight NUTS 2 units, called development regions (lacking any administrative status), and 41 NUTS 3 units, called counties (included in the national administrative hierarchy). Bucharest, the capital, represents the 42nd NUTS 3 unit, due to its size and importance. Within each county, the base administrative units, cities and communes, correspond to NUTS 5/Land Administrative Units (LAU) level 2 divisions. 
In addition to them, within the framework of 2007-2013 Regional Operational Programme seven Romanian cities were designated as "growth poles" Braşov, Cluj-Napoca, Constanţa, Craiova, Iaşi, Ploieşti, and Timişoara, and thirteen as "urban development poles" - Arad, Baia-Mare, Bacău, Brăila, Galaţi, Deva, Oradea, Piteşti, Râmnicu-Vâlcea, Satu Mare, Sibiu, Suceava, Târgu-Mureş (Government of Romania, 2008). In addition, the "urban centers" are cities with a population over 10,000, other than the "growth poles" and "urban development poles".

\section{URBAN VERSUS SPATIAL PLANNING: PROCEDURES, DOCUMENTS, PLANS}

The first approaches to urbanism in Romania represent also a premiere in Europe. Cincinat Sfinţescu (1887-1955), a Romanian civil engineer, completed his education in Romania (School of Bridges and Highways in Bucharest, 1910), Germany (Technische Hochschule in Cherlottenburg, 1913), and France. His work experience includes local administration, higher education, and research (Derer, 2008). His achievements, including elaborating plans for Bucharest (1916, 1921-1934, 1949-1954), Bazargic/Tolbuhin (1929), editing a new Romanian-based journal on urbanism ("Urbanismul” - The Urbanism) with international circulation, creating the Urban Library, research and academic activity (courses, conferences, and publications), and membership in international professional associations ensured his international reputation (Derer, 2008). Due to his plans, Bucharest emerged as a prominent European capital city (Machedon et al., 1999).

From a theoretical standpoint, Cincinat Sfinţescu's most important contribution was represented by coining in 1929 a new concept, called "super-urbanism" or "national urbanism", corresponding to what is called today "spatial planning" (Cristea, 2008). In a 1934 paper, he defined several terms already in circulation: "systematization" was the planning the layout of specific objectives (street, square, or entire settlement), aiming to underline the main spatial issues; "urbanization" represented, at different spatial scales, the planning of more settlements, underlining their community of interests; and "super-urbanism" described the spatial organization at the national level (Popescu-Criveanu, 2008).

Urbanism was affected by changes during the communist regime too. Systematization, the concept used before, was redefined and applied primarily to the rural settlements, attempting to transform them into cities. However, the 
approach was not directed to meet some minimum living standards and/or enhance the infrastructure, but to the replacement of traditional architecture with Soviet blocks of apartments, some lacking the basic utilities (centralized water and heating supplies).

After 1989, the concept of "systematization" was no longer used, since the Communist interpretation perverted its true meaning. Under the French influence, two levels of territorial planning were distinguished: urbanism applies to the base administrative units (communes and the composing villages, cities, and municipalities), while spatial planning (called in Romanian "amenajarea teritoriului", translation of the French "aménagement du territoire", literally "territorial arrangement/layout") was applied to the larger divisions (county and regions formed by more counties or parts of them).

Urbanism and spatial planning do not differ only by scale; Romanian Law no. 350 of 2001 on spatial planning and urbanism (The Parliament of Romania, 2001a) shows that spatial planning is global (coordinates different sectoral policies in a holistic entity), functional (accounts for the natural and built environment based on common values and interests), prospective (involves the economic, ecological, social, and cultural trends), and democratic (provides for the participation of population and its representatives), while urbanism is operational (details and delimits in the territory the results of spatial planning), integrative (synthesizes sectoral policies on managing the administrative territory), and normative (specifies how land is used, defines the designation and size of buildings, including infrastructure, utilities, and plantations). Moreover, both activities result into urban and spatial planning documents and regulations, consisting of drawn plans, and texts. Spatial planning documents include directing proposals (main strategies and evolutionary directions for territories), while urbanism documents are operational (transpose in the territory the provision of spatial planning documents through concrete regulations related to land use and building permissions). Spatial planning regulations are mandatory for all public administration authorities, while urbanism regulations are obligatory for citizens and their associative structures.

The spatial planning documents include the National Spatial Plan (consists of several sections, each approved by law, some of them under work, and some only proposed), Regional Spatial Plans (for more base administrative units within the same county, parts of counties, or entire counties), and County 
Spatial Plans (for a single county, including all its base administrative units). The urban plans include the General Urban Plan and its corresponding Regulation of Urbanism (for entire base administrative units), the Zonal Urban Plan and its corresponding Regulation of Urbanism (for parts of the base administrative units), and the Detailed Urban Plan (for one or more specific objectives). Examples of these plans are displayed in Fig. 1.

In addition, the "urban centers", "growth poles", and "urban development poles" must have an Integrated Plan of Urban Development, as a part of the Regional Operational Programme regulations (Ministry of Development, Public Works, and Housing, 2007). An Integrated Urban Plan was elaborated for one of the six sectors of Bucharest (\#4), consisting of an inventory and prioritization of the 1,350 plans and studies in a „modern, complex, and superior approach to urban and infrastructure issues" (Inimăroiu, 2008). According to the proposed Strategic Concept of Territorial Development for 2030 in Romania (Ministry of Development, Public Works, and Housing, 2008) the Regional Operational Programme, Integrated Plan of Urban Development, and Integrated Urban Plan are not attempting to replace the existing spatial and urban planning documents, but instead complete them from a strategic perspective (Fig. 2).

The building permit is the final act based on urban plans (which in their turn rely on spatial planning documents), and, by law, represents the obligatory informative act specifying the juridical, economic, and technical regime of buildings and conditions for any real estate operations.

\section{EDUCATION IN SPATIAL PLANNING AND URBANISM}

By their nature, urban/spatial planning has an interdisciplinary and multidisciplinary character, and requires the participation of specialists from different disciplines. In addition, specific competences are required. Due to the huge responsibility of the professionals, a public institution was created in 2004 and assigned the responsibility to monitor urban/spatial planning, namely the Romanian Registry of Urbanists, which is also a member of the European Council of Town Planners (ECTP). The law that governs its current functioning (The Superior Council of the Romanian Registry of Urbanists, 2006) defines the urbanist as a professional qualified by education (at least a Bachelor's degree) or practice; among urbanists, the "urbanists with diploma" are those with a Bachelor's degree granted in urbanism after a course of studies of at least five years in the pre-Bologna system, or 3/4 years plus a Master's degree in the Bologna system; in addition to them, the law also calls 
PLANUL DE AMENAJARE A TERITORIULUI NATIONAL SECTIUNEA a IV-a - RETEAUA DE LOCALITATI
RETEAUA DE LOCALTATI URBANE

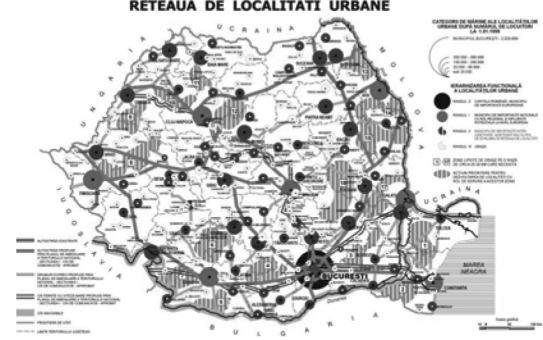

National Spatial Plan, Section IV:

Network of settlements (Parliament of Romania, 2001b) urban settlements

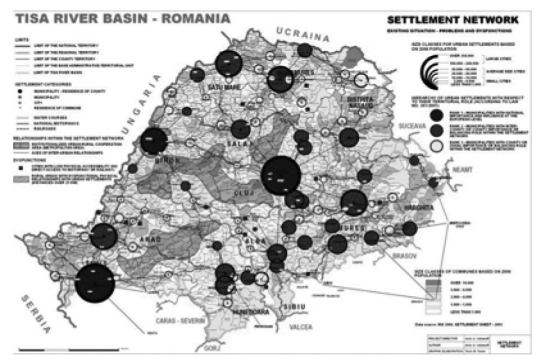

Zonal Plan: Romanian part of Tisa river basin - network of settlements (Cocean et al., 2007)

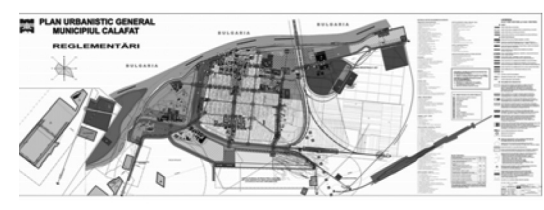

General Urban Plan: the city Calafat - proposed regulations (Antal, 2005)

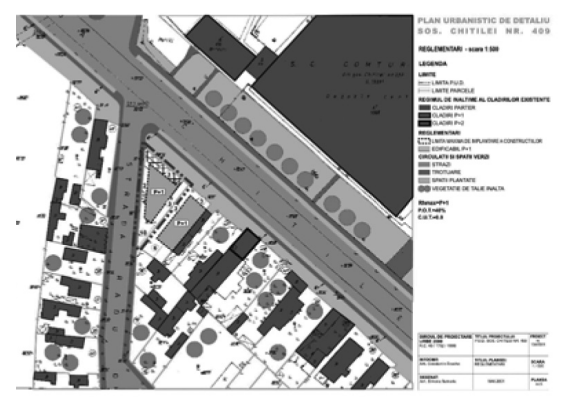

Detailed Plan: Regulations, Chitilei St. \#409, Bucharest (Antal, 2005)

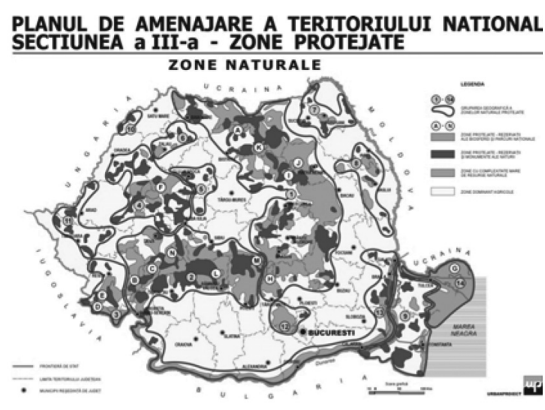

National Spatial Plan, Section III: Protected areas

(Parliament of Romania, 2000) - natural protected areas

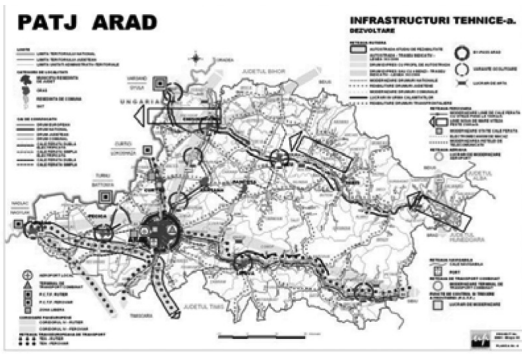

County Plan: Arad County - development of the technical infrastructure (Urbanproiect, 2009)

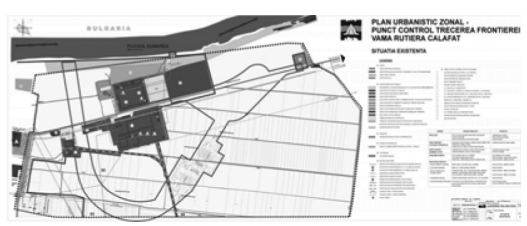

Zonal Urban Plan: highway customs, the city Calafat current situation (Antal, 2005)

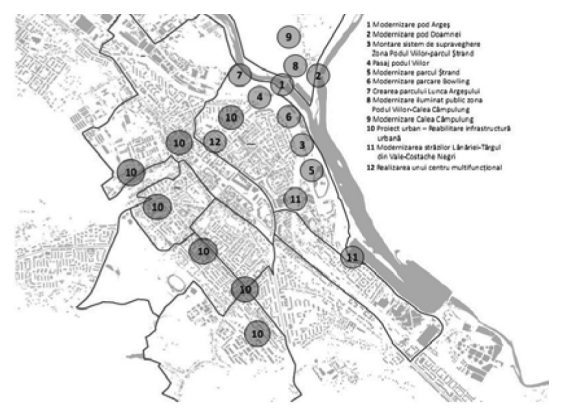

Integrated Plan of Urban Development: Piteşti proposed objectives of development (Valeri, 2009) 
"urbanists" specialists from other disciplines contributing to the elaboration of urban/spatial planning documents, referred, according to their background, as "architect-urbanist" (Bachelor's degree granted in architecture and work experience or a Master's degree in urbanism), "economist - urbanist", "geographer - urbanist", "sociologist - urbanist", "ecologist - urbanist", "engineer - urbanist" etc.

A new proposal, that could replace the existing classification by the time when this paper is published, introduces a new nomenclature, based on the Bologna system; "urbanists" are the specialists with a 4-years degree recognized in the European Union and attested by the Romanian Registry of Urbanists; "urbanists with diploma" are those with a 5-years degree attested by the Romanian Registry of Urbanists by 2009; "master-urbanists" are those with a 4-years degree, plus a Master's degree based on at least 90 credits; the title is attested by the Romanian Registry of Urbanists cumulating the Bachelor's and Master's degrees. "Architects-urbanists" hold a 5-years Bachelor's degree in architecture and work experience of 6 years for those who graduated before 2002 or a 2-years Master's degree in urbanism/spatial planning with at least 120 credits. Finally, a "economists - urbanists", "sociologists - urbanists", "geographers - urbanists", "jurists - urbanists", "engineers - urbanists", or "ecologists - urbanists" hold a Bachelor's degree in their first discipline and either a 2-years Master's degree in urbanism/spatial planning with at least 120 credits or 6-years professional experience in urbanism/spatial planning.

A specific professional background added by the new proposal is "landscaper". While such degrees are awarded by either the Faculty of Urbanism at "Ion Mincu" University of Architecture and Urbanism in Bucharest and the Faculty of Horticulture at the University of Agronomy and Veterinary Medicine (the later were called "landscape engineers"), only the graduates of the first institution are entitled to be qualified as spatial planners. Nevertheless, formerly called "landscape engineers" can either acquire professional experience (6 years) or pursue a Master's degree in urbanism/spatial planning (2 years, 120 credits) and become, according to the proposed legislative project, "landscapers - urbanists". The graduates of the first institution are called "urbanists - landscapers" if they hold a 4-years degree recognized in the European Union and attested by the Romanian Registry of Urbanists, "landscapers with diploma" if they have a 5-years degree attested by the Romanian Registry of Urbanists by 2009, "master - urbanists - landscapers" if they have a 4-years degree, plus a Master's degree based on at least 90 credits; the title is attested by the Romanian Registry of Urbanists cumulating 
the Bachelor's and Master's degrees, and "architects - landscapers" if they have a 5-years Bachelor's degree in architecture and work experience of 6 years for those who graduated before 2002 or a 2-years Master's degree in urbanism/spatial planning with at least 120 credits.

The changes of law correspond to the changes in the education system. First of all, the qualification in urbanism received its legal recognition recently. The first Bachelor's degree in urbanism was awarded by the Faculty of Urbanism at "Ion Mincu" University of Architecture and Urbanism in Bucharest in 2002, five years after the foundation of the new Faculty; currently, this institution is the only one in Romania offering degrees in urbanism. In addition to the Bachelor's degrees, Master's level programs were started after adopting the Bologna system (the programs included in the current offer are: (1) Spatial Planning and Regional Development, (2) Integrated Urban Development, (3) Urban Management, and (4) Urbanism and Administration). The award of $\mathrm{PhD}$ degrees is still debated; as a consequence, currently when $\mathrm{PhD}$ degrees are awarded, some members of the doctoral committees propose a degree in urban/spatial planning, while others propose a degree in architecture. Graduating classes before 2002 did not receive a degree in urbanism, but can be qualified as "urbanists" by their professional experience.

By December 2009, the Romanian Registry of Urbanists had already attested the rights of signature for 1,418 architects, 125 urbanists, and 104 specialists with other backgrounds (economy, sociology, ecology, geography, etc.). Out of them, most were from Bucharest (441 architects, 87 urban planners, and 42 other specialists).
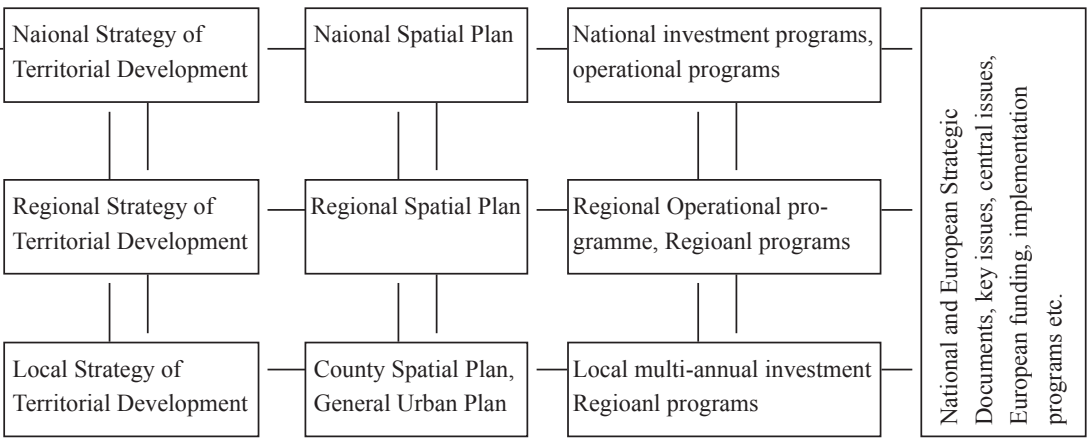


\section{THE ACTORS}

In the previous sections, the educators and their issue have been described. However, provided the participative and regulatory sides of urbanisms, other actors must be defined as well. These actors are the central and local authorities.

The need for a central structure became evident shortly after 1989, in accordance with a need for an executive authority, responsible for implementing the legislation urban/spatial planning. Started 8 January 1990, the National Commission on Urbanism and Spatial Planning became a department of the newly created Ministry of Public Works, Transport and Spatial Planning on 28 June 1990 and later, during different administrations and under different names, based on the political interests, was part of different ministries (Ministry of Public Works, Transport and Spatial Planning until 1991, Ministry of Public Works and Spatial Planning until 2000, Ministry of Public Works, Transport and Housing until 2007, Ministry of Development, Public Works, and Housing until 2008, and Ministry of Regional Development and Housing until 2009). At the present time, it is called the "Department of Territorial Development" and is part of the Ministry of Regional Development and Tourism.

The local administrative structures are the Departments of Urbanism, led by the architect-chief of the county, municipality, or city. It has to be stressed out that currently the term "architect-chief" denotes a position, and not a professional background. Currently, for many counties, and for even more municipalities or cities, the position is occupied by people without a degree and/or professional experience in architecture or urbanism. For this reason, the Romanian Registry of Urbanists and the Ministry of Regional Development and Tourism are preparing a legislative incentive aiming to condition the occupation of this position by an appropriate professional background, and require the current occupants to complete their education in urbanism.

By law, two specific commissions, with a consultative role, had been established within the two chambers of the Parliament. The Commission for Public Administration, Spatial Planning, and Ecological Equilibrium functions within the Chamber of Deputies, while the Commission for Public Administration, Territorial Organization, and Environmental Protection belongs to the Senate.

The initiative of elaborating urban/spatial planning documents belongs to local collectivities, through their administration, to the Government, and 
to anyone interested. Funds are provided for by the local budgets, the state budget (via the coordinating Ministry), and by any interested investor. The Department of Territorial Development within the Ministry of Regional Development and Tourism coordinates a research institution, the National Research and Development Institute for Constructions, Urbanism, and Sustainable Territorial Development "Urban-Incerc". Apart from its involvement in research projects and programs coordinated by the Ministry of Education, Research, Youth, and Sports, or by other Romanian or European institutions, "Urban-Incerc" is responsible for the elaboration of the specific sections of the National Spatial Plan, as well as studies related to specific zonal plans and other initiatives of the Ministry. Other research activities, including the elaboration of urban/spatial planning documents and connected studies (especially for the county level and below), can be carried out in addition by several actors, including the universities, research institutes, and private companies, based on public procurement procedures and specific funding programs. Upon their elaboration, urban/spatial planning documents undergo specific procedures, consisting of their acceptation by technical committees within the ministries or local authorities and final approval by the central or local authorities. The approval is a bureaucratic process conditioned by the existence of the acceptance proofs, which is essential for urban/spatial planning documents since they can be sued in justice courts and constitute the background of local and regional development. Recent incentives aiming to reduce bureaucracy and simplify the bureaucratic procedures are likely to affect urbanism and spatial planning too, even though the most complicated procedures (related to environmental impact assessment) are more likely to complicate the approval process in this case instead of simplifying it.

\section{THE LAWS}

While many legislative instruments, including local regulations, govern both urban and spatial planning, the core framework consists of several organic laws, some of which were mentioned before. All these legislative instruments had been modified and completed by other laws upon their promulgation by the Parliament, and some are still under review. The Constitution defines the administrative units. Law no. 50 of 1991 regulates the authorization of construction works, conditioning it upon the issuance of a building permit. Consequently, the building permit is conditioned by the existence of a valid Certificate of Urbanism, which in its turn relies on approved urban and spatial plans. Law no. 350 of 2001 defines urban and spatial planning and their objectives, enumerates their specific procedures and the attributions of 
institutional actors, central and local, as well as the specific plans and documents. The Governmental Decision no. 525 of 1996, named the General Regulation of Urbanism, is a unitary system composed of specific technical and juridical regulations governing the urbanism activities. Governmental Decision no. 26 of 2006 regulates the functioning of the Romanian Registry of Urbanists and the process of obtaining the rights of signing the coordination and/or elaboration of urban and/or spatial planning documents or parts of these. Specific sections of the National Spatial Plan were already approved (Water - Law no. 171 of 1997, Protected Areas - Law no. 5 of 2000, Human Settlements Network - Law no. 351 of 2001, Areas of Natural Risk - Law no. 575 of 2001, Transport Networks - Law no. 363 of 2006, and Touristic Areas - Law no. 190 of 2009), while other are in course of completion (Educational Infrastructure, and Rural Areas). The Civil Code and specific guidelines, approved by the line Ministry, constitute the legal framework for elaborating urban and spatial plans, and for the legal resolution of eventual conflicts. In addition, provisions from the legislation of environmental protection, public administration, and other sectors are applicable to urban and spatial planning as well. The European legislation, including the European Urban Code, is applied over the Romanian territory too.

\section{CONCLUSIONS}

The paper attempted to analyze urban and spatial planning in Romania, especially in the historical context of a case study looking at a formerly communist country moving to an open-market economy and joining the European Union. The historical changes influenced many sectors, including planning. However, one particularity of Romania is the distinction between the two spatial levels of planning: urban and spatial. The distinction is not a consequence of the recent changes, but originates from the inter-wars development of theoretical and practical urbanism. Another characteristic of Romania is the regulatory aspect, reflected in the planning activities and corresponding educational background. In planning, the regulatory aspects have determined the emergence of a bureaucratic process, involving the approval of plans by local and central authorities. Educational changes relate to the emergence of new professions, particularly as a consequence of the Bologna process. On a timeline, dramatic changes occurred in both cases after the installment of the communist regime, after the return to democracy, and after joining the European Union. However, the first two periods are characterized by changes only during their beginning, while joining the European Union constitutes the start point of changes that are still ongoing. 
The changes in education are particularly important when trying to create a unitary system for assessing the qualification of specialists formed by different educational programs, corresponding to the needs of different historical periods, but also to the fact that their potential market has enlarged. presentation delivered at the Ministry of Transport, Constructions, and Housing, Bucharest, Romania [available on CD].

Choay F. (1965), Urbanism: utopias and realities. An anthology (in French), Aux Éditions du Seuil, Paris, ISBN 20200583284, 348 pp.

Cocean P., Vartanoff A., Sorocovschi V., Păcurar A., Florescu L., Filip S., Dumitru V., Chicoş A., Crişan A., Oncu M., Niculescu V., Chiperi F., Ciangă N., Zaharescu D., Dorobanţu M., Har N., Stancu E., Irimuş I., Vescan I., Surdeanu V., Moldovan F., Man T., Cocean R., Moldovan C., Boia N., Tache M., Ivana C., Dumitru M., Pâslaru B., Vâlceanu V., Petrişor A.-I., Papp L., Synthetical approach to the Romanian Tisa Basin, Romanian Review of Regional Studies 3(1):1-132.

Cristea D. (2008), Super-urbanism: milestones for the present (in Romanian), Urbanismul. Serie nоиӑ 1(1):8-13.

Derer P. (2008), Cincinat Sfinţescu, technician of urbanism (in Romanian), Urbanismul. Serie nоuă 1(1):14-15. 
Emlen J. T. (1974), An urban bird community in Tucson, Arizona: Derivation, structure, regulation, Condor 76:1184-197.

Erskine A. J. (1992), Urban area, commercial and residential, American Birds 26:1000.

Hendrix W. G., Fabos J. G., Price J. E. (1988), An ecological approach to landscape planning using geographic information system technology, Landscape and Urban Planning 15:211-225.

Herzog T. R., Chernick K. K. (2000), Tranquility and danger in urban and natural settings, Journal of Environmental Psychology 20:29-39.

Inimăroiu A. (2008), Integrated Urban Plan: Concept, elaboration, implementation in Sector 4 of Bucharest (in Romanian), informative brochure, Bucharest, 158 pp.

Lacaze J.-P. (1990), Methods of Urbanism (in French), Second Edition, Presses Universitaires de France, Paris, 127 pp., ISBN 978-2130452140, pp. 16, 40.

Machedon F., Machedon L., Scoffham E. (1999), Inter-war Bucharest: city in a garden, Planning Perspectives 14(3):249-275.

McIntyre N. E., Knowles-Yánez K., Hope D. (2000), Urban ecology as an interdisciplinary field: differences in the use of "urban" between the social and natural sciences, Urban Ecosystems 4:5-24.

Mills E. S., Hamilton B. W. - Editors (1989), Urban Economics (4th Edition), HarperCollins, Glenview, IL, USA, ISBN 978-0673383235, 461 pp.

Odum E. P. (1997), Ecology: A Bridge Between Science and Society, Sinauer Associates, Sunderland, MA, SUA, ISBN 978-0878936304, 330 pp.

Péchoin D. - Coordinator (1995), Little colored Larousse dictionary (in French), Larousse, Paris, ISBN 2-03-301331-6, $1784 \mathrm{pp}$.

Petrişor A.-I. (2008), Urban ecology, sustainable spatial development, and legislation (in Romanian), Editura Fundaţiei România de mâine, Bucharest, Romania, ISBN 978-973-163305-3, 272 pp.

Petrişor L. E. (2010), Involvement of urbanism and spatial planning specialists in the development of urban and rural areas of Romania (in Romanian), Amenajarea teritoriului şi urbanismul 10(1-2):44-47.

Popescu-Criveanu Ş. (2008), “Ab initio” urban terminology: the inter-war period (in Romanian), Urbanismul. Serie nouă 1(1):16-19.

The Government of Romania (2008), Decision no. 1149 of 18 September 2008 on the modification and completion of the Decision of the Government no. 998 of 2008 on the designation of national growth poles, where investments from community and national funded programs represent priorities, The Official Gazette 719, 23 October 2008

The Ministry of Development, Public Works, and Housing (2007), The 2007-2013 Regional Operational Program (in Romanian), Publication of the Romanian Government, Bucharest, Romania, $246 \mathrm{pp}$.

The Ministry of Development, Public Works, and Housing (2008), The Strategic Concept of Territorial Development for 2030 in Romania (in Romanian), General Division for Territorial Cohesion Strategies and Policies, Bucharest, Romania, $71 \mathrm{pp}$.

The Parliament of Romania (2000), Law no. 5 of 6 March 2000 on the approval of the National Spatial Plan, Section III: Protected areas, The Official Gazette 152, 12 April 2001

The Parliament of Romania (2001a), Law no. 350 of 6 July 2001 on spatial planning and urbanism, The Official Gazette 373, 10 July 2001

The Parliament of Romania (2001b), Law no. 350 of 6 July 2001 on the approval of the National Spatial Plan, Section IV: Network of settlements, The Official Gazette 408, 24 July 2001

The Superior Council of the Romanian Registry of Urbanists (2006), Governmental Decision no. 26 of 2006 on the approval of the Regulation for obtaining signature rights for spatial planning and urbanism documents and Regulation of the organization and functioning of the Romanian Registry of Urbanists, The Official Gazette 853, 18 October 2006 
Urbanproiect (2004), AMTRANS 1A01. Conceptual and methodological model. Guide of specific terminology (in Romanian), Bucharest, Romania, http://www.rur.ro/ghid.pdf.

Urbanproiect (2009), Spatial plan of Arad County: Update. Phase III: Spatial development strategy and program of actions (in Romanian), Project no. 6961/2007, Bucharest, Romania, http://www. mdrt.ro/_documente/dezvoltare_teritoriala/amenajarea_teritoriului/patj_arad/etapa_III.pdf.

Valeri V. (2009), Integrated Plan of Urban Development - Piteşti (in Romanian), Bucharest, Romania, http://www.rur.ro/ghid.pdf. 